УДК 664.8.047

DOI 10.30679/2219-5335-2022-1-73-243-262

ПРИМЕНЕНИЕ

БИО-ПЛЕНОК

В ТЕХНОЛОГИИ ХРАНЕНИЯ

И ПЕРЕРАБОТКИ

ПЛОДОВО-ЯГОДНОГО СЫРЬЯ

Дрофичева Наталья Васильевна

канд. техн. наук

старший научный сотрудник

лаборатории хранения

и переработки плодов и ягод

e-mail: Droficheva.nata@icloud.com

Федеральное государственное

бюджетное научное учреждение

«Северо-Кавказский федеральньий

научный иенттр садоводства,

виноградарства, виноделия»,

Краснодар, Россия

Фрукты и овощи являются источником незаменимого комплекса биологически активных веществ, необходимых для поддержания здоровья человека. По данным Минсельхоза России объемы сборов фруктов за период 2014-2019 выросли на более чем на $10 \%$. Сезонность плодово-ягодного производства определяется технологией хранения собранной продукции с расчетом на ее использование в течение длительного срока, что возможно в условиях системы сохранения качества сырья как в свежем виде, так и в переработаном. Отмечается, что потери при хранении свежей плодово-ягодной продукции (в зависимости от вида) могут составлять более $30 \%$. Ценной альтернативой полиэтиленовой упаковке представляется разработка пленок из биоразлагаемых полимеров и высокомолекулярных соединений, являющихся пригодными для употребления человеком в пищу. Формируемые непосредственно на поверхности свежих и переработанных фруктов защитные биоразлагаемые покрытия зачастую более надежно препятствуют окислительной и микробиальной порче за счет отсутствия
UDC 664.8.047

DOI 10.30679/2219-5335-2022-1-73-243-262

\section{THE USE OF BIO-FILMS \\ IN THE TECHNOLOGY \\ OF STORAGE AND PROCESSING \\ OF FRUIT AND BERRY \\ RAW MATERIALS}

Droficheva Natalia Vasilievna

Cand.Tech.Sci.

Senior Research Associate

of Storage and Processing

of Fruits and Berries Laboratory

e-mail: Droficheva.nata@icloud.com

\section{Federal State Budget}

Scientific Institution

«North Caucasian Federal

Scientific Center of Horticulture,

Viticulture, Wine-making»,

Krasnodar, Russia

Fruits and vegetables are a source of an indispensable complex of biologically active substances necessary to maintain human health. According to the Ministry of Agriculture of Russia, the volume of fruit harvests for the period 2014-2019 increased by more than $10 \%$. The seasonality of fruit and berry production is determined by the storage technology of the harvested products with the expectation of its use for a long time, which is possible in the conditions of the system of preserving the quality of raw materials both fresh and processed. It is noted that losses during storage of fresh fruit and berry products (depending on the type) can be more than $30 \%$. A valuable alternative to polyethylene packaging is the development of films from biodegradable polymers and high-molecular compounds that are suitable for human consumption. Formed directly on the surface of fresh and processed fruits, protective biodegradable coatings often more 
прослойки воздуха. Био-пленки единственный вид биоразлагаемой полимерной упаковки, которая не нуждается в индивидуальном сборе и особых условиях утилизации. Основными пленкообразующими компонентами для получения съедобных упаковок являются: природные полисахариды, вещества белковой, липидной природы и их комбинации. Основные способы нанесения пленкообразующих компонентов: окунание, распыление, полив и нанесение кистью. Наиболее экономически выгодно для c/х производств использовать метод распыления, ввиду экономичного расхода покрытия и снижения трудозатрат.

Съедобные полимерные пленки предотвращают потерю влаги, контролируют обмен кислорода и углекислого газа, придают устойчивость к изменению качества в целом. Кроме того, привлекательными для потребителя съедобные пленки делает дополнительное наличие в их составе полезных для здоровья веществ, таких как витамины, минералы, биофлавоноиды, всевозможные экстракты и т.п.

Ключевые слова: БИО-ПЛЕНКИ, ФРУКТЫ, ОВОЩИ, ХРАНЕНИЕ, ПОКРЫТИЕ. reliably prevent oxidative and microbial spoilage due to the absence of an air layer. Bio-films are the only type of biodegradable polymer packaging that does not need individual collection and special disposal conditions. The main film-forming components for obtaining edible packages are: natural polysaccharides, substances of protein, lipid nature and their combinations. The main methods of applying film-forming components: dipping, spraying, watering and applying with a brush. It is most cost-effective for agricultural production to use the spray method, due to the economical consumption of coating and reduced labor costs. Edible polymer films prevent moisture loss, control the exchange of oxygen and carbon dioxide and give resistance to quality changes in general. In addition, attractive to the consumer edible films makes the additional presence in their composition of healthy substances, such as vitamins, minerals, bioflavonoids, all kinds of extracts, etc.

Key words: BIO-FILMS, FRUITS, VEGETABLES, STORAGE, COATING

Введение. Фрукты и овощи являются товаром первой необходимости, а обеспечение населения страны качественной плодоовощной продукцией является важнейшей народнохозяйственной задачей. Спрос на плодоовощную продукцию постоянно увеличивается. Рынок овощей - один из важнейших сегментов продовольственного рынка, что определяется значением овощей для питания и здоровья населения. Обеспечение населения страны качественной овощной продукцией в требуемых объемах является важной социальной задачей [1-3].

Совершенствование организации производства в отрасли связано с созданием на крупных сельскохозяйственных предприятиях и оптовых плодоовощных рынках маркетинговых служб, главными задачами которых 
Плодоводство и виноградарство Юга России № 73(1), 2022 г.

являются исследование конъюнктуры рынка, контроль своевременного сбыта продукции, изучение рыночных цен по основным каналам продаж, прогнозирование объемов реализации плодоовощной продукции, информирование населения о ее качестве, ассортименте и ценах. В последние годы в нашей стране потребление овощей характеризуется тенденцией к росту, динамика роста потребления овощей выражена в большинстве российских регионов. Российский рынок фруктов также характеризуется устойчивой тенденцией к росту: темпы увеличения его объема составляют около $15 \%$ в год. Основными факторами, влияющими на развитие рынка, выступают уровень цен на фрукты и благосостояние населения, как индикатор общей покупательской способности. Также значительное влияние на динамику рынка фруктов в России оказывают факторы сезонности и качества фруктов [2-4].

Однако российский рынок плодоовощной продукции, в отличие от западного, в силу исторических и климатических факторов имеет свои особенности. В большинстве регионов страны свежие овощи из открытого грунта используются всего четыре-шесть месяцев в году. В остальное время они поступают в свежем виде частично из защищенного грунта, но в основном из хранилищ или после переработки в разнообразные продукты. Важнейшим условием рационального использования плодоовощной продукции, снижения потерь и более полного удовлетворения потребностей населения, является развитие сети длительного хранения продукции [4-5].

В стране ежегодно производится около 4 млн. т фруктов и овощей. Однако потери при хранении этой продукции составляют более 30 \%. В результате в зимне-весенний период большая часть населения в зимневесенний период потребляет овощи, которые закладываются на хранение осенью или импортируются. Равномерное поступление плодоовощной продукции по сезонам года возможно лишь в условиях хорошо налаженной системы её длительного хранения в свежем виде, поэтому организация 
хранения и переработки картофеля, овощей и фруктов является важной государственной задачей [5].

Способы и методы хранения плодоовощной продукции достаточно консервативны, но новые исследования позволили усовершенствовать существующие технологии. Увеличилась продолжительность хранения свежих овощей и фруктов, появились новые способы охлаждения и хранения продуктов, что значительно улучшает их качество [6-9].

Важнейшей задачей в рыночных условиях хозяйствования является повышение качества сельскохозяйственных продуктов при хранении и переработке. Сохранность плодоовощной продукции зависит от соблюдения научно-обоснованных режимов хранения. Заготовку, хранение и переработку плодоовощной продукции осуществляют плодоовощные базы, которые поставляют ее для потребностей населения городов, на перерабатывающие заводы государственного подчинения, коллективной и частной собственности. Усилия всех заготовительных и перерабатывающих организаций направлены на максимальное снижение потерь при транспортировке, хранении и переработке сельскохозяйственной продукции. Качество закладываемой на хранение продукции во многом определяет их сохранность. Длительному хранению подлежит только здоровая продукция высокого качества, соответствующая требованиям стандартов. Издержки при хранении и переработке продуктов снижаются по мере создания более совершенной технической базы, внедрения новых технологических приемов, повышения квалификации специалистов [10-16].

Во всем мире сейчас интенсивно развивается направление биоразлагаемых материалов для сохранности качества фруктов и овощей, а также улучшения экологической обстановки [17-19].

При выборе биоразлагаемой пленки в качестве альтернативы обычной полиэтиленовой потребитель ко всем преимуществам обычного пла- 
стика получает уникальное свойство - возможность материала безопасно разлагаться, не угрожая жизни людей, животных растений.

Обсужжение. Фрукты и овощи являются источником незаменимого комплекса биологически активных веществ, необходимых для поддержания здоровья человека. По данным Минсельхоза России объемы сборов фруктов за период 2014-2019 выросли на более чем на 10 \% (рис. 1).

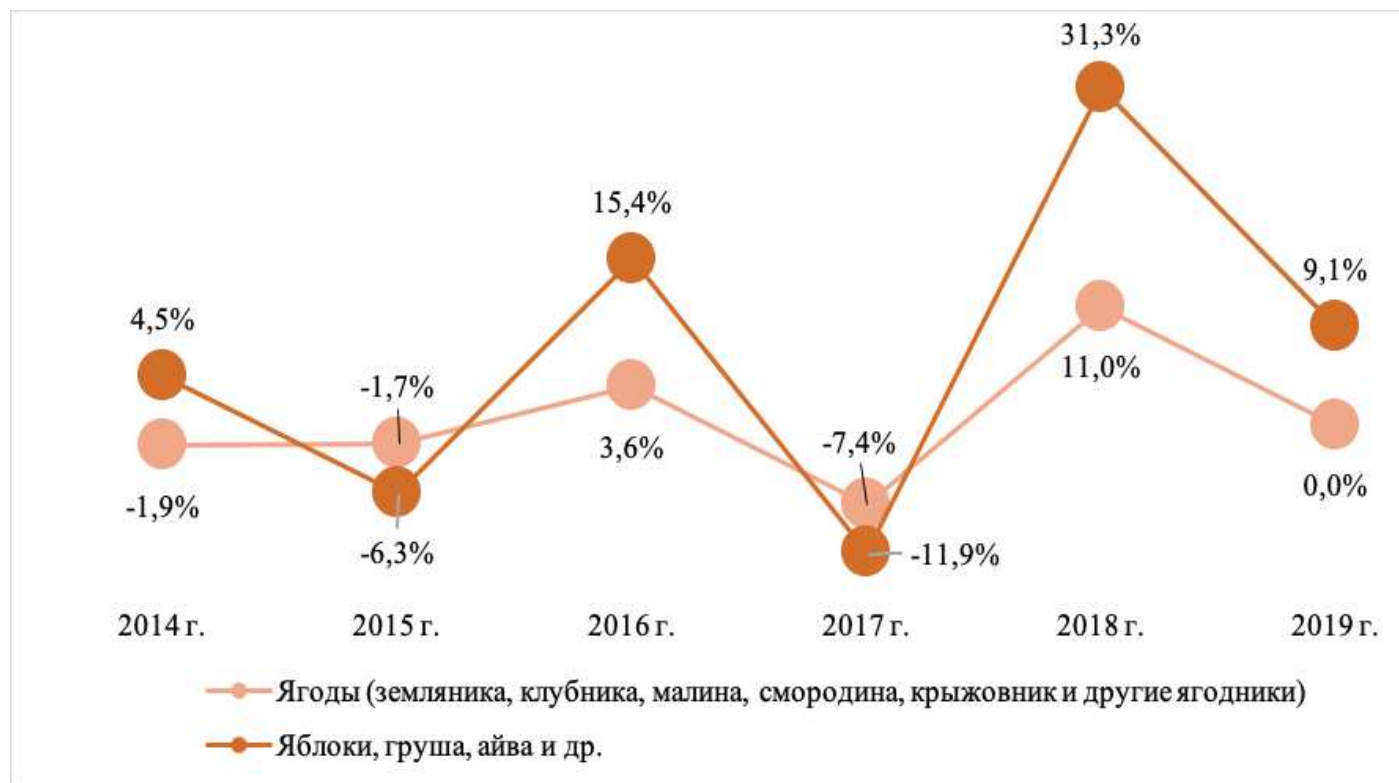

Рис.1. Оценка плодово-ягодного рынка

Сезонность плодово-ягодного производства определяется технологией хранения собранной продукции с расчетом на ее использование в течение длительного срока, что возможно в условиях системы сохранения качества сырья как в свежем виде, так и в переработаном. Отмечается, что потери при хранении свежей плодово-ягодной продукции (в зависимости от вида) могут составлять более $30 \%$ [19].

Перспективным направлением, по данным AgroPK, в сохранении свежести продукции является применение различных технологий упаковки плодово-ягодного сырья. Некоторые производители перед закладкой на хранение используют полиэтиленовую пленку толщиной 30-40 мкм. К примеру, яблоки, слива и земляника в такой пленке хранятся дольше, и 
увеличивается процент выхода стандартных плодов. Естественная убыль уменьшается в 6 раз. Но при выборе пленки толщиной более 40 мкм углекислый газ накапливается внутри упаковки из-за низкой газопроницаемости [20]. В настоящее время учеными разработано несколько видов материалов для упаковки и хранения плодово-ягодного сырья (рис. 2).

К сожалению, большую часть используемых в промышленности пленок для хранения плодово-ягодной продукции получают из плохо разлагаемых синтетических материалов.

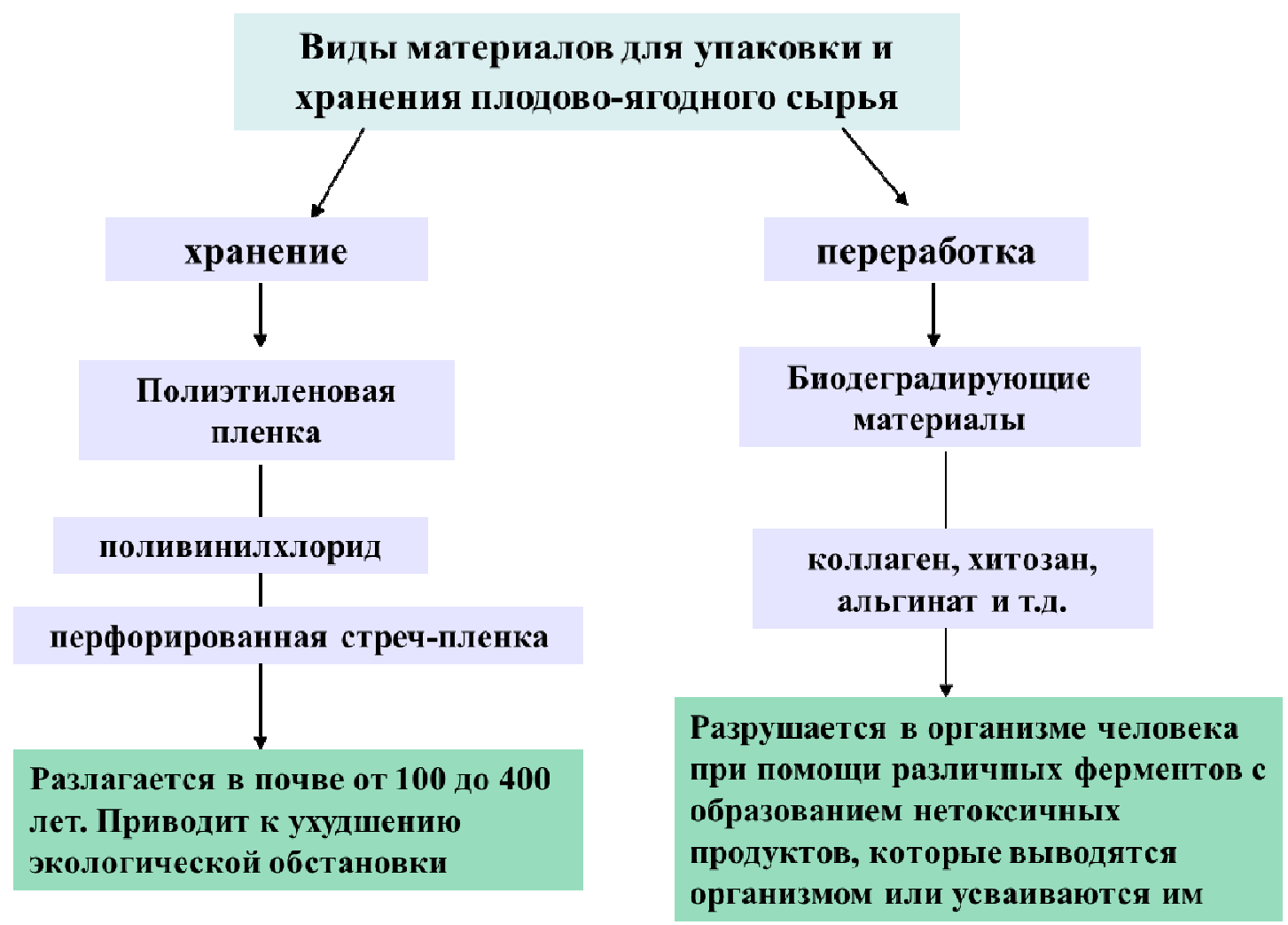

Рис. 2. Виды материалов для упаковки и хранения плодово-ягодного сырья

По данным журнала Univer Science современный пластик уже признан истинным мировым бедствием. Статистика говорит, что за год человек выбрасывает более 100 кг упаковочных материалов. Роспотребнадзор готовит поправки в законодательство о поэтапном сокращении полиэтиленовой упаковки до 2024 года. Ценной альтернативой полиэтиленовой упа- 
ковке представляется разработка пленок из биоразлагаемых полимеров и высокомолекулярных соединений, являющихся пригодными для употребления человеком в пищу. Формируемые непосредственно на поверхности свежих и переработанных фруктов защитные биоразлагаемые покрытия зачастую более надежно препятствуют окислительной и микробиальной порче за счет отсутствия прослойки воздуха [17-19]. Био-пленки - единственный вид биоразлагаемой полимерной упаковки, которая не нуждается в индивидуальном сборе и особых условиях утилизации. Интенсификация - повышение эффективности производства путем полного использования каждой единицы ресурсного потенциала (рис. 3).

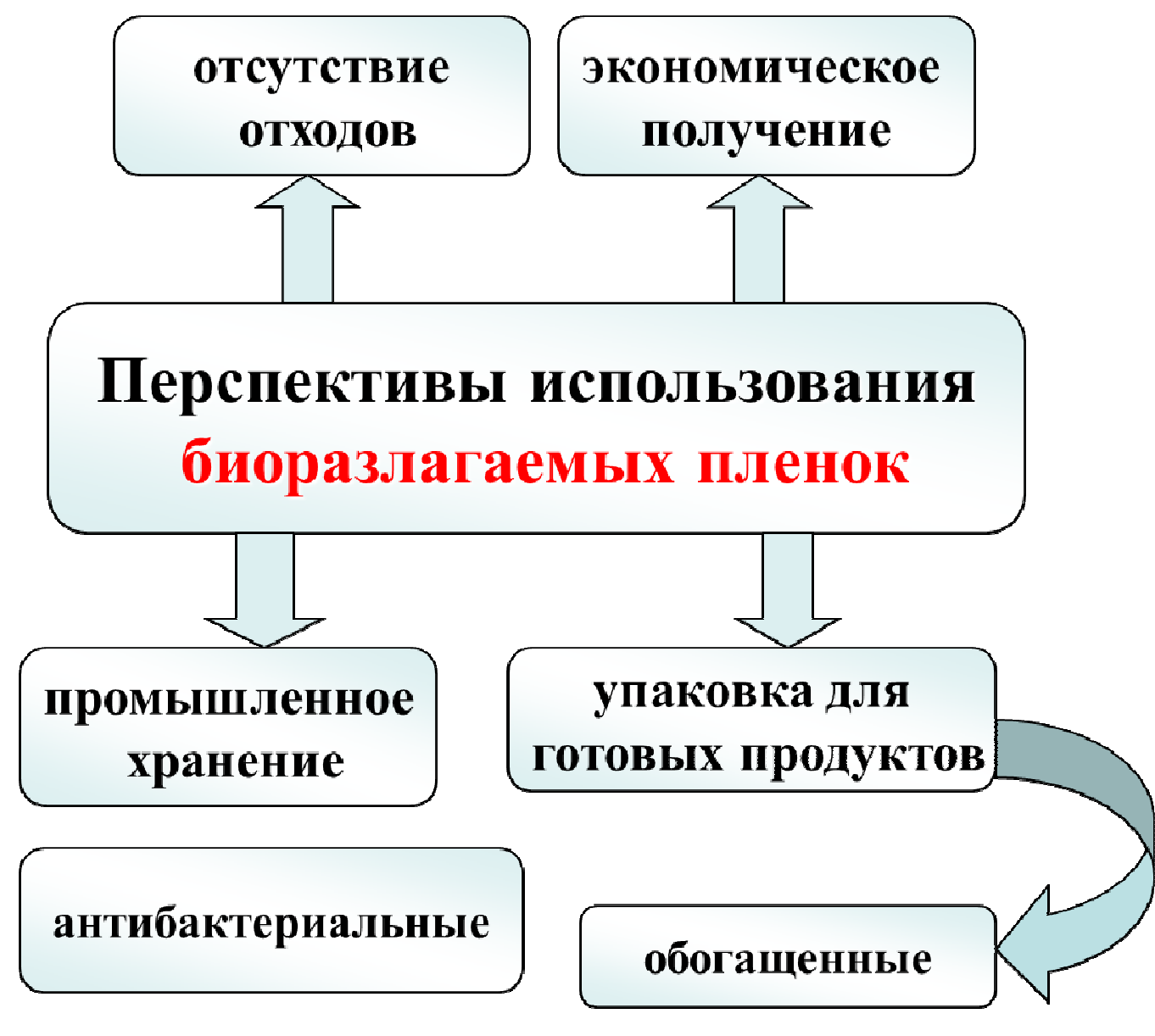

Рис. 3. Перспективы использования биоразлагаемых пленок 
Основными пленкообразующими компонентами для получения съедобных упаковок являются: природные полисахариды, вещества белковой, липидной природы и их комбинации [20-23].

Так, пленки полисахаридов гидрофильны и позволяют получить широкий спектр композиционных упаковочных материалов, поскольку в пленку можно ввести различные водорастворимые добавки: ароматизаторы, красители и др. компоненты. Они прочно связываются с основным полимером водородными связями.

Особое внимание разработчиков и исследователей уделяется такому полисахариду как хитозан. Его растворы дают однородные, гибкие пленки, которые обладают антибактериальными свойствами. На продуктах с таким покрытием микробы и другие микроорганизмы не размножаются. Профессор Янюн (Yanyun Zhao) из университета Орегона в США и специалисты из университета Дели используют это свойство для увеличения срока хранения свежих фруктов и расширения экспорта местных продуктов, в частности, манго, нарезанных яблок и черники [21].

Большой интерес для сохранения качества плодово-ягодной продукции представляет пуллулан - нейтральный водорастворимый полисахарид, полученный путем ферментации крахмала посредством гриба Aureobasidium pullulans. Он не токсичен для человека и животных, полностью биоразлагаем и низкокалориен, имеет хорошие адгезионные характеристики, при тонком нанесении не проницаем для кислорода и оказывает влияние на подавление роста большинства протестированных микроорганизмов, ответственных за разложение пищевых продуктов, поэтому он может быть полезным элементом для обеспечения микробиологической безопасности пищевых продуктов. В Японии и США пуллулан используют для производства биоразлагаемых пластиков, ввиду его схожести с основными свойствами полиэтилена и может использоваться для изготовления кислородонепроницаемых пленок и волокон, загустителей или наполнителей, а также инкапсулирующих агентов [22-23]. 
Плодоводство и виноградарство Юга России № 73(1), 2022 г.

Белковые пленки также гидрофильны, поэтому, как и полисахаридные, хорошо пропускают пары воды. Департамент сельского хозяйства США разработал пищевые казеиновые пленки. Казеин - белок, содержащийся в молоке, и упаковку из него используют для сыра и йогурта. Из-за стоимости технологии пока производство экспериментальной пленки удалось наладить лишь на маленьком заводе в Техасе. В Чешской республике производят съедобные пленки EDICOL R, они изготавливаются из чистого говяжьего коллагена, получаемого из шкур КРС [24].

Липидные пленки обладают хорошими барьерными свойствами по отношению к влаге, но характеризуются невысокой механической прочностью. В Санкт-Петербурге, в национальном исследовательском университете разрабатываются покрытия на липидной гелевой основе для продления сроков хранения овощей и фруктов, а также для придания им дополнительных свойств. Александр Подшивалов утверждает, что в этом геле есть микропоры, благодаря которым могут происходить процессы обмена водяным паром и газами с окружающей средой, высыхания или, наоборот, впитывания влаги. За счет толщины гелевого покрытия и добавления в его состав функциональных компонентов можно контролировать эти процессы, то есть их интенсивность, скорость, а также придавать продукту новые товарные характеристики [25].

Например, с помощью антиоксиданта, введенного в состав покрытия, можно уменьшить количество кислорода, который контактирует с поверхностью плода. Таким образом, замедлится окисление поверхности. В Белоруском государственном университете в 2017 году разработаны липидные полимерные покрытия. Одной из наиболее полезных функций которых является наличие барьерных свойств по отношению к этилену [26].

Основные способы нанесения пленкообразующих компонентов: окунание, распыление, полив и нанесение кистью. Наиболее экономически выгодно для с/х производства использовать метод распыления, ввиду экономичного расхода покрытия и снижения трудозатрат. 
Плодоводство и виноградарство Юга России № 73(1), 2022 г.

Большое внимание ученых посвящено изучению влагопроницаемости, влияния температурных режимов на биоразлагаемые пленки и их принципу разложения. Ученым Китая Юньтао Лю по данным журнала Биолоджикал Макромолекулс доказано положительное влияние использования биоразлагаемых пленок на основе хитозана и глицерина. При низких температурах скорость потери массы земляники постепенно снижалась по сравнению с хранением в полиэтилене и без упаковки. Чем выше было содержание хитозана и глицерина, тем меньше была потеря веса земляники. Изменения цвета ягоды при хранении более заметны при температуре $24{ }^{\circ} \mathrm{C}$, чем при $4^{\circ} \mathrm{C}$. Причина заключалась в том, что, с одной стороны, высокая температура увеличивала синтез антоцианов, а с другой - увеличивала потерю жидкости, что привело к увеличению концентрации пигмента в клетках. Из опыта видно, что упаковочный материал на основе хитозана с разной молекулярной массой, и глицерином улучшает механические свойства и стабильность качества ягоды, в сравнении с контролем и полиэтиленом (рис. 4) [27-28].

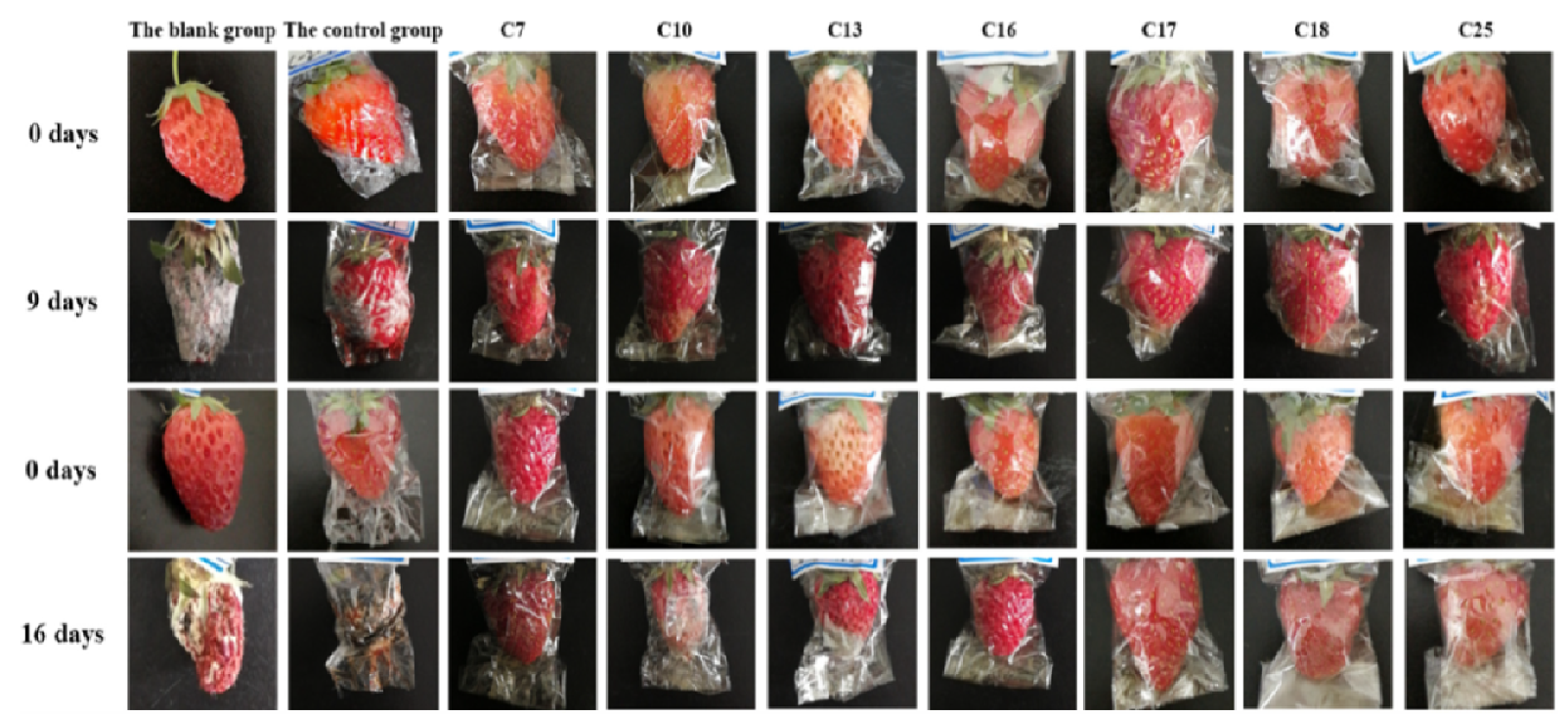

Рис. 4. Использование биоразлагаемых пленок: хитозан х глицерин 
Некоторые российские ученые изучают принципы разложения биопленок, большая часть которых, в зависимости от ее природы, разлагается от 7 до 100 дней (рис. 5).

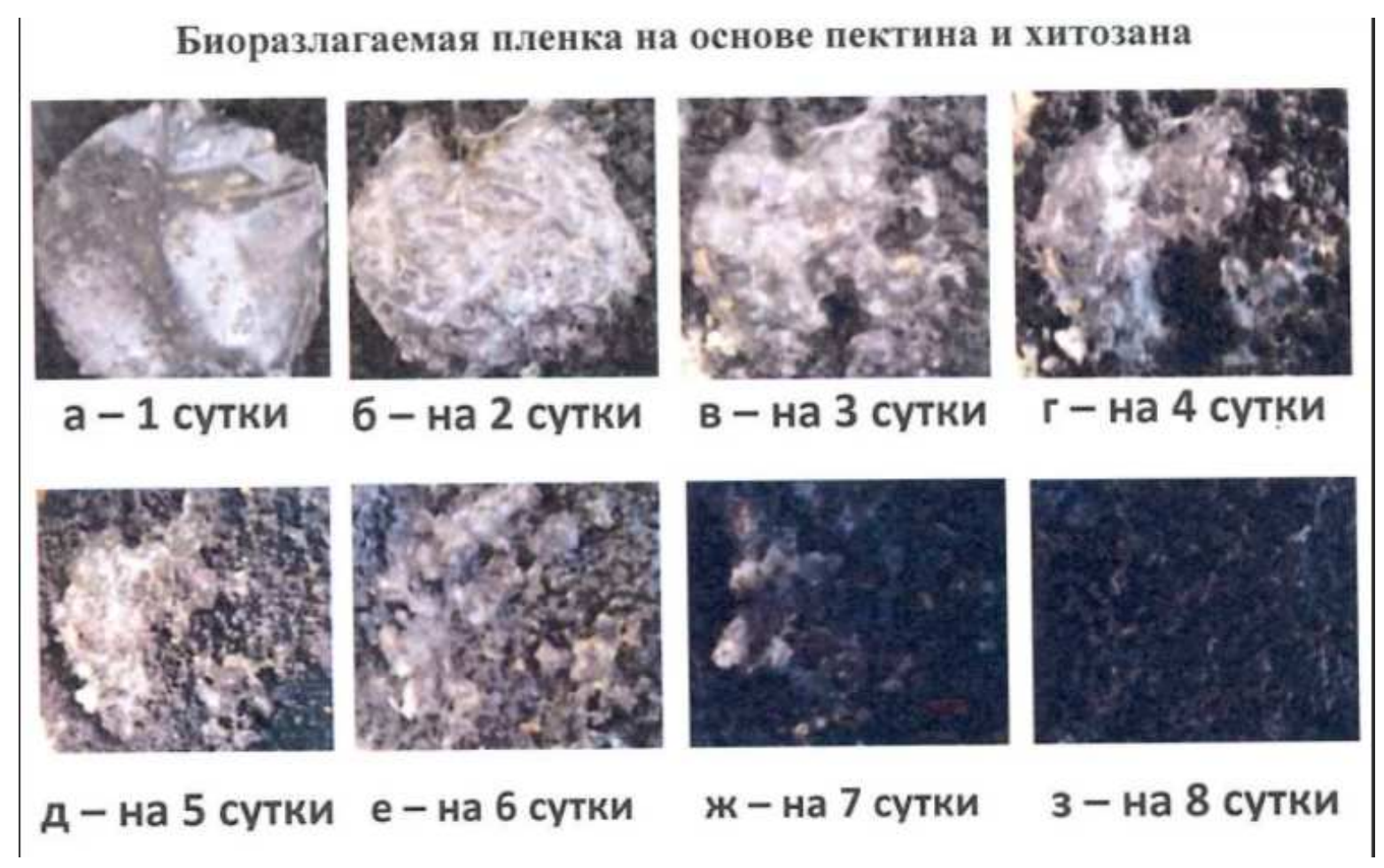

Рис. 5. Принцип разложения био-пленок

Биологизация технологий производства съедобных пленок получает широкое развитие в пищевой промышленности. Для каждого типа продуктов необходимо разрабатывать разные виды покрытий, невозможно создать «единое» покрытие, так как разные продукты имеют разные химикобиологические свойства.

Съедобные полимерные пленки предотвращают потерю влаги, контролируют обмен кислорода и углекислого газа и придают устойчивость к изменению качества в целом. Кроме того, привлекательными для потребителя съедобные пленки делает дополнительное наличие в их составе полезных для здоровья веществ, таких как витамины, минералы, биофлавоноиды, всевозможные экстракты и т.п. Активно этой проблемой занимают- 
Плодоводство и виноградарство Юга России № 73(1), 2022 г.

ся ученые Германии, которые создали полимерные вещества из различных съедобных материалов: крахмала, желатина, природных целлюлоз, а также разработали упаковку из альгината $\mathrm{Na}$ и Са, выделенного из бурых морских водорослей, специально для одной из сетей фастфуда Nordsee [29].

По природе основных компонентов, образующих пленку, можно выделить два класса веществ: одни - это биополимеры или липиды, а другие - пищевые продукты в виде овощных, фруктовых пюре, крахмала и т.п. Основу съедобных пленок, в состав которых входят соки и пюре, составляют пектиновые вещества. При получении пленки пищевые компоненты предварительно подвергают дегидратации вымораживанием.

Ученые ОАО «Борисовский завод полимерной тары «Полимиз» в сотрудничестве с БГУ разработали съедобную пленку, которая состоит из крахмала и пищевых полимеров. Она отлично усваивается организмом, увеличивает срок хранения продуктов, а также подходит для нанесения печати съедобными чернилами. Такую пленку можно использовать при упаковке конфет, специй, меда, спортивного питания, витаминных добавок [30].

Ученые Самарского политехнического университета представили технологию получения биоразлагаемых съедобных пленок на основе отходов переработки яблок - яблочных выжимок.

Исследователи Пизанского университета (Италия) предложили использовать в качестве сырья для создания биоразлагаемого пластика молочную сыворотку, которая является побочным продуктом сыродельческих предприятий. Помимо остатков молочной продукции, ценным сырьем могут выступать также и другие сельскохозяйственные отходы.

Бразильская корпорация сельскохозяйственных исследований и компания Embrapa Instrumentation создали съедобные пленки из фруктовых и овощных соков с добавлением жирных кислот, спиртов, воска и растительного масла. Они не только увеличивают срок хранения, но и позволяют потребителю самому выбрать их вкус [31]. 
Плодоводство и виноградарство Юга России № 73(1), 2022 г.

Американский ученый Тара Макхью (Tara McHugh) разработала упаковочную пленку из фруктовых и овощных пюре, которая увеличивает срок хранения продуктов, а также обладает пищевой ценностью [32].

Итальянские ученые использовали пищевые пленки для обогащения яблочных цукатов пробиотиками. Цукаты были покрыты пленками метилцеллюлозы, содержащими фруктоолигосахариды и лактобактерии [33].

Пример использования белковых пленок в пищевой перерабатывающей промышленности - покрытие на основе зеина. Пленки в этом случае проявляют хорошие барьерные свойства по отношению к влаге, поэтому было предложено использовать их для упаковки изюма, чтобы предотвратить влаги потерю из изюма и сохранить качество сухих смесей, в которые он входит. Аналогичный продукт под торговой маркой Cozeen от компании ZumbroINc. Hayfield сегодня используют для покрытия орехов, конфет [34].

Российские ученые Астраханского политехнического института в 2019 году разработали сьедобные пленки из ихтиожелатина с разной паропроницаемостью (плотная и тонкая для растяжения), продлевающие сроки хранения более чем на 100 дней.

В Японии для аналогичной цели начали использовать микробиальный полисахарид - геллановую камедь KELGOGEL, которую производят микроорганизмы Pseudomonas elodea. Этот полимер стал известен только в последнее десятилетие, но по своим свойствам, он похож на альгинат, хотя в отличие от него может образовывать гели с различными ионами. Предлагается использовать смесь ацилированной и деацилированной формы геллановой камеди с аскорбиновой кислотой для получения съедобной пленки с антиоксидантными свойствами. Доказано, что увеличение содержания в пленке деацилированного полимера и ионов кальция повышает способность аскорбиновой кислоты подавлять процесс ферментативного побурения, которое приводит к появлению коричневого цвета при хранении нарезанных яблок. Такое изменение цвета продукта не влияет на вкус, но не 
удовлетворяет эстетическим потребностям покупателя. Еще одно направление применения съедобных пленок - это упаковка свежевымытых ягод, нарезанных фруктов и других продуктов «ready-toeat» (RTE, т.е. готовых к употреблению). Расширение возможностей использования RTE продуктов связано с еще одной важной функцией съедобных пленок и покрытий - антимикробной. Антимикробная функция съедобной упаковки, предполагающая наличие бактерицидных и фунгицидных свойств, весьма востребована сегодня вследствие изменения образа жизни современных покупателей [35-37].

Антимикробные съедобные пленки и покрытия имеют ряд преимуществ и представляют собой инновационную концепцию биоразлагаемых активных упаковок с большими перспективами применения в области консервирования пищевых продуктов.

Получение опытных партий биоразлагаемых пищевых пленок из яблочного и вторичного сырья сокового производства, также как и обогащенных снеков и цукатов биологически активными веществами для увеличения пищевой ценности и сроков хранения может быть исследовано и в лаборатории хранения и переработки плодов и ягод нашего научного центра (рис. 6).
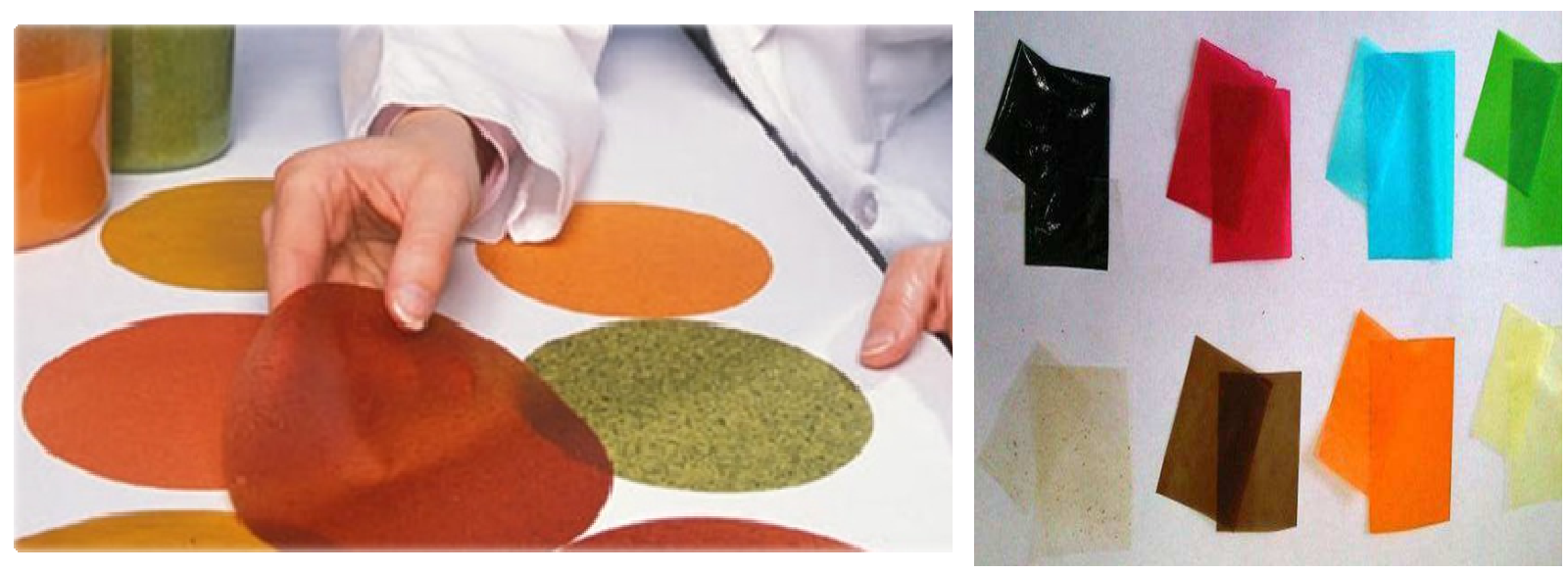

Рис. 6. Натуральные био-пленки 
Плодоводство и виноградарство Юга России № 73(1), 2022 г.

Bbыводы. Применение пленкообразующих покрытий и замена синтетических составляющих предметов обихода (пакеты, одноразовая посуда и т.д.) на натуральные компоненты, не приносящие вреда экологии, получает все более широкое распространение в мире. Каждый день ассортимент продуктов питания с био-пленкообразующим покрытием расширяется, пользуется высокой популярностью у населения. Организация производства съедобных пленок и покрытий неизбежно приведет не только к сокращению количества бытовых отходов, но и повышению качества продуктов питания и комфортности их потребления.

\section{Литература}

1. María José Tavera-Quiroza, Nelson Romano, Pablo Mobili, Adriana Pinottia, Andrea Gómez-Zavagli, Nora Bertola // Journal of Functional Foods. Vol. 16. - 2015 - P. 164173. $\quad$ https://www.semanticscholar.org/author/Mar\%C3\%ADa-Jos\%C3\%A9-TaveraQuiroz/1422534318

2. Alsoufi MA, Aziz RA. Extending shelf life of fruits by using some microorganisms biological products // Int J Mol Biol Open Access. Vol. 2. - 2017 - P.00032 https://doi.org/10.15406/ijmboa.2017.02.00032

3. Freimoser, F.M., Rueda-Mejia, M.P., Tilocca, B. et al. Biocontrol yeasts: mechanisms and applications. World J Microbiol Biotechnol Vol. 35. - 2019 - P. 154. https://doi.org/10.1007/s11274-019-2728-4

4. Shukla A., Shukla R.S., Chandan Dasa, Vaibhav V. Goud Gingerols infusion and multi-step process optimization for enhancement ofcolor, sensory and functional profiles of candied mango // Food Chemistry. - Vol. 300. - 2019 - P. 125195. https://doi.org/10.1016/j.foodchem.2019.125195

5. Bellary, A. N. Anthocyanin infused watermelon rind and its stability during storage. /Indiramma, A. R., Prakash, M., Baskaran, R., \& Rastogi, N. K. // Innovative Food Science \& Emerging Technologies. Vol. 33. - 2016 - P. 554-562. https://doi.org/10.1016/j.ifset.2015.10.010

6. Cappa C., Lavelli V., Mariotti M. Fruit candies enriched with grape skin powders: Physicochemical properties // LWT-Food Science and Technology. Vol. 62(1). - 2015 P. 569-575. http://dx.doi.org/10.1016/j.1wt.2014.07.039

7. Tavera-Quiroza M.J., Romano N., Mobili P., Pinottia A., Gómez-Zavagli A., Bertola N. Green apple baked snacks functionalized withedible coatings of methylcellulose containing Lactobacillus plantarum///Journal of Functional Foods. Vol. 16. - 2015 - P. 164-173. https://doi.org/10.1016/J.JFF.2015.04.024

8. Romano N., Gómez-Zavaglia A. Edible methylcellulose-based films containing fructo-oligosaccharides as vehicles for lactic acid bacteria // Food Research International. Vol. 64. - 2014 - P. 560-566. https://doi.org/10.1016/j.foodres.2014.07.018

9. González-Reza R.M. Nanocontainers in food preservation. Techniques and uses Smart Nanocontainers. Micro and Nano Technologies - 2020 - P. 137-155 https://doi.org/10.1016/B978-0-12-816770-0.00009-5 
10. Nunes C., Rato A.E., Barrosa A.S., Jorge A. Saraiva, Manuel A. Coimbra Search for suitable maturation parameters to define the harvest maturityof plums (Prunus domestica L.): A case study of candied plums/ // Food Chemistry Vol. 112. - 2009 - P. 570-57. DOI:10.1016/j.foodchem.2008.06.007

11. Deiana M., Montoro P., Jerkovic I., Atzeria A., Marijanović Z., Serrelia G., Piacente S., Ignazio C., Tuberoso G. First characterization of Pompia intrea candied fruit: The headspacechemical profile, polar extract composition and its biological activities/ // Food Research International. - 2019. - P. 620-630. https://doi.org/10.1016/J.FOODRES.2018.11.016

12. Olua O., Edide, R.O. Chemical, microbial and sensory properties of candiedpineapple and cherry cakes // Nigerian Food Journal. - Vol. 31. - № 1. - 2013. - P. 33-39. https://doi.org/10.1016/S0189-7241(15)30054-0

13. Wan Nurlaila Mat Desa, Mohammad M., Fudholi A. Review of drying technology of fig/ // Trends in Food Science \& Technology. Vol. 88. - 2019. - P. 93-103. https://doi.org/10.1016/j.tifs.2019.03.018

14. Белых Д. А., Касьянов В. К., Аверина Ю. М. Производство эко-упаковок российскими компаниями для кондитерской, мясной и фруктово-овощной продукции. Технологии, инновации, проблемы // Успехи в химии и химической технологии. 2018. T. 32. №14 (210). C. 49-51. https://www.elibrary.ru/item.asp?id=36955094

15. Волова Т. Г. Современные биоматериалы: мировые тренды, место и потенциал микробных полигидроксиалканоатов (пга) // Биотехнология и качество жизни»: материалы международной научно-практической конференции. М. ЗАО «Экспобиохим-технологии», 2014. С. 504-505. https://www.elibrary.ru/item.asp? id=22260063

16. Ультратонкие волокна поли(3-гидроксибутирата) с хитозаном, полученные электроформованием / С.Г. Карпова [и др.] // Вестник Технологического университета. 2015. T. 18. № 13. C. 64-73. https://www.elibrary.ru/item.asp?id=29331507

17. Федотова О. Б., Мяленко Д. М., Шалаева А. В. «Активная упаковка» из полимерных материалов // Пищевая промышленность. 2010. № 1. С. 22-23. https://www.elibrary.ru/item.asp?id=12990060

18. Мяленко Д.М. Биоразлагаемые полимерные материалы для упаковки молочной и пищевой продукции // Молочная промышленность. 2020. № 11. С. 44-46. DOI: 10.31515/1019-8946-2020-11-44-46

19. Чудайкина А.В., Суровцева Е.В., Коляда Л.Г., Тарасюк Е.В. Инновацтонные системы упаковок в пищевой промышленности // Качество в обработке материалов. 2020. - № 1 (12). - C. 64-69. https://www.elibrary.ru/item.asp?id=44676510

20. Ермакова А.А., Андреева И.А., Смирнова А.В. «Активная упаковка» как инновация упаковочной отрасли // В сб.: Качество продукции, технологий и образования. Материалы XIV Международной научно-практической конференции. - 2019. - С. 206210. https://www.elibrary.ru/item.asp?id=41901417

21. Si W., Gong J., Tsao R., Zhou T., Yu H., Poppe C., Johnson R., Du Z. Antimicrobial activity of essential oils and structurally related synthetic food additives towards selected pathogenic and beneficial gut bacteria // J. Appl. Microbiol. - Vol. 100. - 2006. - P. 296-305. https://doi.org/10.1111/j.1365-2672.2005.02789.x

22. Горбатенко Л.А., Волосова Е.В., Безгина Ю.А. Экологические аспекты создания упаковочного материала / Сб. науч. трудов по мат. Международной научнопрактической конференции «Современные тенденции развития науки и технологии». 2018. - C. 24-25. https://www.elibrary.ru/item.asp?id=36568353

23. Stępień A., Witczak M., Witczak T. Moisture sorption characteristics of food powders containing freeze dried avocado, maltodextrin and inulin // International Journal of Biological Macromolecules. - № 149. - 2020. - P. 256-261. https://doi.org/10.1016/j.ijbiomac.2020.01.154 
24. Ногина А.А., Тихонов С.Л., Тихонова Н.В. Арабиногалактан в производстве колбасных изделий из мяса птицы с нехарактерным автолизом // Дальневосточный аграрный вестник. 2018. № 2 (46). C. 128-135. https://www.elibrary.ru/item.asp?id=35727080

25. Volova T. G., Shishatskaya E. I., Sinskey A. J. Degradable Polymers: Production, Properties and Applications. New York: Nova Science Publ. - 2013. - P. 380. https://www.elibrary.ru/item.asp?id=21913038

26. Тихонов С.Л., Тихонова Н.В., Ногина А.А. Технология и оценка качества пищевых пленок // Вестник ВСГУТУ. 2019. № 1 (72). С. 19-28. https://www.elibrary. $\underline{\mathrm{ru} / \mathrm{contents} . \mathrm{asp} ? \mathrm{id}=37182006}$

27. Кудряшов Л.С., Тихонов С.Л., Тихонова Н.В., Ногина А.А. Разработка биоразлагаемой пленки для увеличения срока годности мясных полуфабрикатов // Все о мясе. 2019. № 1. C. 18-21. https://www.elibrary.ru/item.asp?id=36932023

28. Song X., Li R., Li H., Hu Z., Mustapha A., Lin M. Characterization and quantification of Zinc oxide and Titanium dioxide nanoparticles in foods // Food Bioprocess Technol. Vol. 7. - 2014. - P. 456-462. DOI:10.1007/s11947-013-1071-2

29. Raybaudi-Massilia R., Tapia M. S., Mosqueda-Melgar J. Peliculas y recubrimientos comestibles con efecto antimicrobiano. In: Olivas-Orozco G. I., Gonzalez-Aguilar G. A., Martin-Belloso O., Soliva-Fortuny R. (Eds.), Peliculas y recubrimientos comestibles. Propiedades y aplicaciones en alimentos. CIAD, Mexico, 2012. - P. 329-361. https://doi.org/ $\underline{10.22201 / \text { fesz.23958723e.2018.0.153 }}$

30. Nur Hanani, Z. A., Roos Y. H., Kerry J. P. Use and application of gelatin as potential biodegradable packagingmaterials for food products // International Journal of Biological Macromolecules. - Vol. 71. - 2014. - P. 94-102. https://doi.org/10.1016/ j.ijbiomac.2014.04.027

31. Babu Bhagath, Yerramathia Manjula, Kola Beulah, Annem Muniraja, Rammohan Aluru, Madhavi Thirumanyam Structural studies and bioactivity of sodium alginate edible films fabricated through ferulic acid crosslinking mechanism // Journal of Food Engineering. Vol. 301. - 2021. - P. 110566 https://doi.org/10.1016/j.jfoodeng.2021.110566

32. Касьянов Г.И. Биоразрушаемая упаковка для пищевых продуктов // Вестник науки и образования Северо-Запада России. 2015. Т. 1. № 1. С. 112-119. https://www. elibrary.ru/item.asp?id=25415132

33. Abdou E. S., Sorour M. A. Preparation and characterization of starch/carrageenan edible films // International Food Research Journal. 2014. - Vol. 21 (1). - P. 189-193. https://www.semanticscholar.org/paper/Preparation-and-characterization-of-edible-filmsAbdou-Sorour/fe9558c9db26e39576a0a51cb1b95b6823b140c0

34. Ананьев В. В., Банникова О. А., Кирш И. А., Безнаева О. В. Получение комбинированного материала, обладающего повышенными адгезионными свойствами // Передовые пищевые технологии: состояние, тренды, точки роста: сб. науч. трудов I научно-практической конференции с международным участием. М. 2018. С. 417-425. https://www.elibrary.ru/item.asp?id=36626260

35. Mastromatteo M., Lecce L., De Vietro N., Favia P., Del Nobile M. A. Plasma deposition processes from acrylic/methane on natural fibres to control the kinetic release of lysozyme from PVOH monolayer film // Journal of Food Engineering. - Vol. 104. - 2011. P. 373-379. DOI:10.1016/J.JFOODENG.2010.12.032

36. Бахаева А.Н., Ивановский С.К. Оксо-биоразлагаемые полимеры как материал для создания современной упаковки // Молодой ученый. 2015. № 5 (85). С. 122-124. URL: https://moluch.ru/archive/85/15940/ 
37. Zeynep Aytac, Jie Xu, Suresh Kumar Raman Pillai, Brian D Eitzer, Tao Xu, Nachiket Vaze, Kee Woei Ng, Jason C White, Mary B Chan-Park, Yaguang Luo, Philip Demokritou Enzyme- and Relative Humidity-Responsive Antimicrobial Fibers for Active Food Packaging // ACS Appl Mater Interfaces. - 2021. - 50298-20308. https://pubs.acs.org/doi/10.1021/acsami.1c12319.

\section{References}

1. María José Tavera-Quiroza, Nelson Romano, Pablo Mobili, Adriana Pinottia, Andrea Gómez-Zavagli, Nora Bertola // Journal of Functional Foods. Vol. 16. - 2015 - P. 164173. https://www.semanticscholar.org/author/Mar\%C3\%ADa-Jos\%C3\%A9-TaveraQuiroz/1422534318

2. Alsoufi MA, Aziz RA. Extending shelf life of fruits by using some microorganisms biological products // Int J Mol Biol Open Access. Vol. 2. - 2017 - P.00032 https://doi.org/10.15406/ijmboa.2017.02.00032

3. Freimoser, F.M., Rueda-Mejia, M.P., Tilocca, B. et al. Biocontrol yeasts: mechanisms and applications. World J Microbiol Biotechnol Vol. 35. - 2019 - P. 154. https://doi.org/10.1007/s11274-019-2728-4

4. Shukla A., Shukla R.S., Chandan Dasa, Vaibhav V. Goud Gingerols infusion and multi-step process optimization for enhancement ofcolor, sensory and functional profiles of candied mango // Food Chemistry. - Vol. 300. - 2019 - P. 125195. https://doi.org/10.1016/j.foodchem.2019.125195

5. Bellary, A. N. Anthocyanin infused watermelon rind and its stability during storage. /Indiramma, A. R., Prakash, M., Baskaran, R., \& Rastogi, N. K. // Innovative Food Science \& Emerging Technologies. Vol. 33. - 2016 - P. 554-562. https://doi.org/10.1016/j.ifset.2015.10.010

6. Cappa C., Lavelli V., Mariotti M. Fruit candies enriched with grape skin powders: Physicochemical properties // LWT-Food Science and Technology. Vol. 62(1). - 2015 P. 569-575. http://dx.doi.org/10.1016/j.lwt.2014.07.039

7. Tavera-Quiroza M.J., Romano N., Mobili P., Pinottia A., Gómez-Zavagli A., Bertola N. Green apple baked snacks functionalized withedible coatings of methylcellulose containing Lactobacillus plantarum///Journal of Functional Foods. Vol. 16. - 2015 - P. 164-173. https://doi.org/10.1016/J.JFF.2015.04.024

8. Romano N., Gómez-Zavaglia A. Edible methylcellulose-based films containing fructo-oligosaccharides as vehicles for lactic acid bacteria // Food Research International. Vol. 64. - 2014 - P. 560-566. https://doi.org/10.1016/j.foodres.2014.07.018

9. González-Reza R.M. Nanocontainers in food preservation. Techniques and uses Smart Nanocontainers. Micro and Nano Technologies - 2020 - P. 137-155 https://doi.org/10.1016/B978-0-12-816770-0.00009-5

10. Nunes C., Rato A.E., Barrosa A.S., Jorge A. Saraiva, Manuel A. Coimbra Search for suitable maturation parameters to define the harvest maturityof plums (Prunus domestica L.): A case study of candied plums/ // Food Chemistry Vol. 112. - 2009 - P. 570-57. DOI:10.1016/j.foodchem.2008.06.007

11. Deiana M., Montoro P., Jerkovic I., Atzeria A., Marijanović Z., Serrelia G., Piacente S., Ignazio C., Tuberoso G. First characterization of Pompia intrea candied fruit: The headspacechemical profile, polar extract composition and its biological activities/ // Food Research International. - 2019. - R. 620-630. https://doi.org/10.1016/J.FOODRES.2018.11.016

12. Olua O., Edide, R.O. Chemical, microbial and sensory properties of candiedpineapple and cherry cakes // Nigerian Food Journal. - Vol. 31. - № 1. - 2013. - R. 33 - 39. https://doi.org/10.1016/S0189-7241(15)30054-0 
13. Wan Nurlaila Mat Desa, Mohammad M., Fudholi A. Review of drying technology of fig/ // Trends in Food Science \& Technology. Vol. 88. - 2019. - R. 93-103. https://doi.org/10.1016/j.tifs.2019.03.018

14. Belyh D. A., Kas'yanov V. K., Averina Yu. M. Proizvodstvo eko-upakovok rossijskimi kompaniyami dlya konditerskoj, myasnoj i fruktovo-ovoshchnoj produkcii. Tekhnologii, innovacii, problemy // Uspekhi v himii i himicheskoj tekhnologii. 2018. T. 32. №14 (210). S. 49-51. https://www.elibrary.ru/item.asp?id=36955094

15. Volova T. G. Sovremennye biomaterialy: mirovye trendy, mesto i poten-cial mikrobnyh poligidroksialkanoatov (pga) // Biotekhnologiya i kachestvo zhizni»: materialy mezhdunarodnoj nauchno-prakticheskoj konferencii. M. ZAO «Ekspo-biohim-tekhnologii», 2014. S. 504-505. https://www.elibrary.ru/item.asp?id=22260063

16. Ul'tratonkie volokna poli(3-gidroksibutirata) s hitozanom, poluchennye elektroformovaniem / S.G.Karpova [i dr.] // Vestnik Tekhnologicheskogo universiteta. 2015. T. 18. № 13. S. 64-73. https://www.elibrary.ru/item.asp?id=29331507

17. Fedotova O. B., Myalenko D. M., Shalaeva A. V. «Aktivnaya upakovka» iz polimernyh materialov // Pishchevaya promyshlennost'. 2010. № 1. S. 22-23. https://www.elibrary.ru/item.asp?id=12990060

18. Myalenko D.M. Biorazlagaemye polimernye materialy dlya upakovki mo-lochnoj i pishchevoj produkcii // Molochnaya promyshlennost'. 2020. № 11. S. 44-46. DOI: 10.31515/1019-8946-2020-11-44-46

19. Chudajkina A.V., Surovceva E.V., Kolyada L.G., Tarasyuk E.V. Innovacton-nye sistemy upakovok v pishchevoj promyshlennosti // Kachestvo v obrabotke materia-lov. 2020. - № 1 (12). - S. 64-69. https://www.elibrary.ru/item.asp?id=44676510

20. Ermakova A.A., Andreeva I.A., Smirnova A.V. «Aktivnaya upakovka» kak innovaciya upakovochnoj otrasli // V sb.: Kachestvo produkcii, tekhnologij i obrazova-niya. Materialy XIV Mezhdunarodnoj nauchno-prakticheskoj konferencii. - 2019. - S. 206-210. https://www.elibrary.ru/item.asp?id=41901417

21. Si W., Gong J., Tsao R., Zhou T., Yu H., Poppe C., Johnson R., Du Z. Antimicrobial activity of essential oils and structurally related synthetic food additives towards selected pathogenic and beneficial gut bacteria // J. Appl. Microbiol. - Vol. 100. - 2006. - P. 296-305. https://doi.org/10.1111/j.1365-2672.2005.02789.x

22. Gorbatenko L.A., Volosova E.V., Bezgina Yu.A. Ekologicheskie aspekty sozdaniya upakovochnogo materiala / Sb. nauch. trudov po mat. Mezhdunarodnoj nauchnoprakticheskoj konferencii «Sovremennye tendencii razvitiya nauki i tekhnologii». - 2018. S. 24-25. https://www.elibrary.ru/item.asp?id=36568353

23. Stępień A., Witczak M., Witczak T. Moisture sorption characteristics of food powders containing freeze dried avocado, maltodextrin and inulin // International Journal of Biological Macromolecules. - № 149. - 2020. - R. 256-261. https://doi.org/10.1016/j.ijbiomac.2020.01.154

24. Nogina A.A., Tihonov S.L., Tihonova N.V. Arabinogalaktan v proizvod-stve kolbasnyh izdelij iz myasa pticy s nekharakternym avtolizom // Dal'nevostoch-nyj agrarnyj vestnik. 2018. № 2 (46). S. 128-135. https://www.elibrary.ru/item.asp?id=35727080

25. Volova T. G., Shishatskaya E. I., Sinskey A. J. Degradable Polymers: Production, Properties and Applications. New York: Nova Science Publ. - 2013. - R. 380. https://www.elibrary.ru/item.asp?id=21913038

26. Tihonov S.L., Tihonova N.V., Nogina A.A. Tekhnologiya i ocenka kachestva pishchevyh plenok // Vestnik VSGUTU. - 2019. - № 1 (72). - S. 19-28. https://www.elibrary.ru/contents.asp?id=37182006 
27. Kudryashov L.S., Tihonov S.L., Tihonova N.V., Nogina A.A. Razrabotka biorazlagaemoj plenki dlya uvelicheniya sroka godnosti myasnyh polufabrikatov // Vse o myase. - 2019. - № 1.- S. 18-21. https://www.elibrary.ru/item.asp?id=36932023

28. Song X., Li R., Li H., Hu Z., Mustapha A., Lin M. Characterization and quantification of Zinc oxide and Titanium dioxide nanoparticles in foods // Food Bioprocess Technol. Vol. 7. - 2014. - P. 456-462. DOI:10.1007/s11947-013-1071-2

29. Raybaudi-Massilia R., Tapia M. S., Mosqueda-Melgar J. Peliculas y recubrimientos comestibles con efecto antimicrobiano. In: Olivas-Orozco G. I., Gonzalez-Aguilar G. A., Martin-Belloso O., Soliva-Fortuny R. (Eds.), Peliculas y recubrimientos comestibles. Propiedades y aplicaciones en alimentos. CIAD, Mexico, 2012. - P. 329-361. https://doi.org/10.22201/fesz.23958723e.2018.0.153

30. Nur Hanani, Z. A., Roos Y. H., Kerry J. P. Use and application of gelatin as potential biodegradable packagingmaterials for food products // International Journal of Biological Macromolecules. - Vol. 71. - 2014. - P. 94-102. https://doi.org/10.1016/ j.ijbiomac.2014.04.027

31. Babu Bhagath, Yerramathia Manjula, Kola Beulah, Annem Muniraja, Rammohan Aluru, Madhavi Thirumanyam Structural studies and bioactivity of sodium alginate edible films fabricated through ferulic acid crosslinking mechanism // Journal of Food Engineering. Vol. 301. - 2021. - R. 110566 https://doi.org/10.1016/j.jfoodeng.2021.110566

32. Kas'yanov G.I. Biorazrushaemaya upakovka dlya pishchevyh produktov // Vestnik nauki i obrazovaniya Severo-Zapada Rossii. 2015. - T.1 - № 1. - S. 112-119. https://www.elibrary.ru/item.asp?id=25415132

33. Abdou E. S., Sorour M. A. Preparation and characterization of starch/carrageenan edible films // International Food Research Journal. 2014. - Vol. 21 (1). - P. 189-193. https://www.semanticscholar.org/paper/Preparation-and-characterization-of-edible-filmsAbdou-Sorour/fe9558c9db26e39576a0a51cb1b95b6823b140c0

34. Anan'ev V. V., Bannikova O. A., Kirsh I. A., Beznaeva O. V. Poluchenie kombinirovannogo materiala, obladayushchego povyshennymi adgezionnymi svojstvami // Peredovye pishchevye tekhnologii: sostoyanie, trendy, tochki rosta: sb. nauch. trudov I nauchno-prakticheskoj konferencii s mezhdunarodnym uchastiem. M. 2018. S. 417-425. https://www.elibrary.ru/item.asp?id=36626260

35. Mastromatteo M., Lecce L., De Vietro N., Favia P., Del Nobile M. A. Plasma deposition processes from acrylic/methane on natural fibres to control the kinetic release of lysozyme from PVOH monolayer film // Journal of Food Engineering. - Vol. 104. - 2011. P. 373-379. DOI:10.1016/J.JFOODENG.2010.12.032

36. Bahaeva A.N., Ivanovskij S.K. Okso-biorazlagaemye polimery kak mate-rial dlya sozdaniya sovremennoj upakovki // Molodoj uchenyj. 2015. № 5 (85). S. 122-124. URL: https://moluch.ru/archive/85/15940/

37. Zeynep Aytac, Jie Xu, Suresh Kumar Raman Pillai, Brian D Eitzer, Tao Xu, Nachiket Vaze, Kee Woei Ng, Jason C White, Mary B Chan-Park, Yaguang Luo, Philip Demokritou Enzyme- and Relative Humidity-Responsive Antimicrobial Fibers for Active Food Packaging // ACS Appl Mater Interfaces. - 2021. - 50298-20308. https://pubs.acs.org/doi/10.1021/acsami.1c12319. 